\title{
REFLECTION
}

\section{When It's Time to Retire: Notes From the Afterlife}

David Loxterkamp, MD

Seaport Community Health Center, Belfast, Maine
Conflict of interest: author reports none.

\section{CORRESPONDING AUTHOR}

David Loxterkamp, MD

Seaport Community Health Center 53 Schoodic Drive

Belfast, ME 04915

davidloxterkamp@gmail.com

\begin{abstract}
At the end of the Second World War, the US birth rate peaked at nearly 27 births per 1,000 population-a rate unparalleled in the previous 3 decades, and one that would not be repeated. That Boomer generation is now retiring. How do those of us caught in the wave feel about stepping back? Who will step in to replace us? And how will we replace the loss of purpose and fulfillment that comes from a career in medicine? A lengthening life expectancy has challenged many of us to consider the "second act" to our adult life. This essay describes the emotional turbulence of ending one career and contemplating the next.

I am in a dark and crowded banquet ball. The faces of those around me are only vaguely familiar, but soon I recognize my medical assistant, a nurse, an old friend and colleague. Everyone is laughing and drinking. I suddenly realize that this is the practice's annual boliday party. Someone asks me if it is time to read the Christmas Poem, a parody of "The Night Before Christmas" that I bave written and performed for the last 30 years. I search my pockets, my vest, my empty bands. And realize that I may bave forgotten to write one this year. No matter; it seems as if no one noticed, and the party churns merrily on. I startle-anxious, exbausted, confused-to the pulse of my alarm, just in time to shower and rush toward another workday.
\end{abstract}

Ann Fam Med 2018;16:171-174. https://doi.org/10.1370/afm.2204.

M ost of my patients call me "Doc." Inside the boundaries of this blue-collar community, I wouldn't respond to any other name. Nor would I have given it a second thought until I decided to retire at the age of 64 .

From the start, retirement demanded hard answers: "Have I saved enough money?" "How will I pay for my health insurance, or coverage for my younger wife and still eligible son?" "If I decide to stay on in some capacity, am I still qualified for the job?" "If I decide to slow down or leave, what will I do with my free time?"

More oblique questions began to surface, like the wistful queries in the globe of an Eight-Ball toy. "Who am I when I am not at work?" "What is pushing me out the door?" "What would I be missing if I stayed in the game?" One cannot twist forever on a string of interrogatories, so I developed pat answers for those who were curious about my retirement. "It's a work in progress," I would smile, or "I'm still working at it."

While colleagues of mine have soldiered on into their 80 s, I knew a year ago that my time was up. The old durable sense of purpose and drive had begun to shift. I wondered aloud what it would be like to be a grandparent, a volunteer, or world traveler. Self-confidence gave way to doubt ${ }_{i}$ frustration nibbled away at the joy I derived from patient care. Ecclesiastes seemed to speak directly to me: "To every thing there is a season, and a time to every purpose under the heaven."

What keeps doctors in the saddle long past their prime is often the devil they don't know, a looming, foreboding afterlife of insignificance and decline. For now, we are cardholders in one of the most exclusive clubs in America. Our work is challenging, well-compensated, much appreciated, and in demand. It engages us with smart, curious, and, for the most part, 
like-minded colleagues. Very few of us are ready to give it up, even when we know we should.

The dream of last December came as I was stepping down from my role as a primary care physician. I had already resigned as the medical director for a 50 -employee primary care practice, and now provided just enough acute care to qualify for benefits. It would be useful and satisfying work, I reassured myself. Less demanding. More focused. It would also signal the end of a career that had defined, bedeviled, and ultimately fulfilled me.

\section{THE PRACTICE}

Through my general practice I have come to know them for more than 3 decades. They are the town's teachers and ministers, garlic and dairy farmers, window makers and boat builders, fast-food cashiers and corporate climbers, home schoolers and retired military. You can find their names on the portraits of old sea captains in the local maritime museum and the rolls of our welfare recipients. They are as proud and old and white as the state of Maine, a people slow to talk and wary to welcome "folks from away." But oh, the nuggets of wisdom in the few words they would spare.

They care for my kids, service my car, bag my groceries, deliver my mail, mow the lawn, and grease the local wheels of commerce, industry, and government. In turn, I have injected, sutured, and delivered them, attended them in the hospital and called on them in their homes; exhorted, supported, and escorted them to their eternal rest. They know me by my argyle socks and straight bowties, standard lines and corny jokes. They often remind me that "I know where to find you," which is around the corner from Blood's Garage, past the blinking light on High Street, up on Salmond Street where we raised our kids and "improved" the Percy McGeorge house, its gardens and vines.

They surely saw it coming. That I was slowing down and cutting back, first giving up OB and hospital rounds a half-dozen years ago; then the nursing home and hospital call; finally, the trimming of my office hours and the closure of my patient panel. As a result, my practice narrowed to the care of old friends in gradual decline. I have had a ringside seat to the multitudinous complaints of an aging population, all variations on a theme that, for the most part, are not amenable to doctors' orders. Yet they tug at my heartstrings $_{i}$ I feel responsible, powerless, sad.

My patients, too, know where they're headed: deep into the uncharted waters of poly-pharmacy, specialty consultations, replacement parts, and rehabilitation. One by one, they have given up winters in Florida; swapped the rambling farmhouse for a condo in town; arranged for CPAP, meals on wheels, and home health aides; braced themselves for an intervention about the driver's license or living alone. And then one day, the sentinel event: A fall. An involuntary drop in weight. Blood on the tissue. And in the blink of an eye, their lives are transformed by the doctor's schedule and treatment plan.

\section{THE DOCTOR}

Since my partners and I sold the business, we are no longer bound by fiscal obligation or administrative duty. We are now employees of a large federally qualified health center, and answer to policies and workflows that are drafted at a distance and tailored to payor incentives. I scrutinize their rules, bristle at them, and bend them according to the needs of my patients. These small acts of defiance might have told me that I was sitting in the exit aisle.

It is true that I have less energy at the end of the day, even as the workload became less taxing. Whereas previously I could scour a stack of articles at my bedside, now I fall asleep before my head hits the pillow. Proper names play hide and seek. I struggle to provide patients with the air of certainty that they or their condition demands. I fret each decision as if each could be the final nail in the coffin of an honorable career.

There comes a time when doctors stop investing in their future. Every new teachable moment begs the question: Do I need to know this? Will I ever use it again? Should I keep my options open or let the board certificate expire? "Keeping up" is yielding diminishing returns. When does a doctor know that his heart is no longer in it? Ambition and energy are closely entwined, and both are essential for maintaining a honed edge. How far can one whittle away the hours and scope of practice until he no longer recognizes the doctor he has now become?

I acknowledge that I may be depressed, or at least depleted. The weight of responsibility has taken its toll. I examine faces in the grocery store, the post office, the YMCA. Have I missed or delayed a diagnosis? Have I offended someone or minimized their needs? I mumble mea culpas. At the end of a career, such thoughts can taint a lifetime of accomplishment with the sting of regret.

\section{A GLASS HALF FULL}

There is no need to nurse a half-empty glass. I realize how lucky I am to be among the surviving $83 \%$ of Americans born in 1953. Half of us again will not turn 80. Leaving a life's work necessarily brings a mixture of emotion, a parting of "such sweet sorrow" that most 
linger "till it be morrow."1 Doctors, especially, know how lucky we are to be alive and purposeful, and how quickly that luck can change.

The employees of the Verso Paper Mill in Bucksport, Maine need no reminding. Three years ago, the mill shuttered its doors, terminating 500 jobs and cutting the local tax base by half. Verso's demise was Maine's fifth such mill closure in recent years, joining Great Northern Paper in East Millinocket, Lincoln Pulp and Tissue, Old Town Fuel and Fiber, and Madison Paper Industries. Maine's paper industry peaked at 18,000 workers in the 1960 s, but now fewer than a third of that number are employed in the industry. Analysts attribute the decline to weak demand, high energy costs and foreign competition-a symptom of the times, and felt not only in Maine but across the rustbelt.

Many of Verso's employees were also patients of mine. For them, the mill closure meant more than the loss of a good paying job; their daily routine, peer group, and sense of identity likewise disappeared. Those who were lucky enough to find work elsewhere now faced a long commute and steep cut in pay.

I am all the more grateful that my employment was never at risk. That the decision to retire was entirely my own. That my patients were, for the most part, fellow taxpayers, parishioners, Friday-night revelers, community gardeners, boosters of the local shops and schools. That I spent my career in a community that was equally committed to me. To my former patients I am still "doc." We are diversely connected, tightly bound.

I have lived an old-fashioned life, one of vows and commitments and faith in the long haul. Buy and hold, we were once taught. Thirty-three years on the job has paid the rent, provided a sense of purpose and routine, and scripted my social interactions. More importantly, it connected me to a peer group and reinforced the ring of reciprocal connections that make up a community. These relationships, like those forged in marriage, family, and friendship, keep growing in value. Over the years they become our pillar of strength when illness and old age chip away at the ordinary pleasures of life.

\section{LIFE AFTER WORK}

I am listening intently to colleagues and friends who recently retired. Every month I return to the "Life After Work Group," a meeting of men in their early 70 s that began 5 years ago. They are strong, proud, and decent men; they earned their retirement and are modest about their accomplishments. Our conversations have become a staple in their less-full lives. They reassure me that less full does not mean less fulfilled.
And I have lunch with retired doctors who have relocated to the area. They are at odds with their stripped-down status, a transitional limbo between celebrated careers and their freedom from it. There are living incognito. Perhaps they hope that I will see them for who they really are, whoever they really are.

To live without the vestments of a career is test of faith. Who am I if not a wage earner, head of a household, or leader of men? Do I know what feeds my soul or have the courage to pursue it? Will my friends and outside interests fill the idle hours? There is no reset button. We own the home, the cars in the garage, a retirement plan, and investment portfolio. We have survived our teenagers and they are (mostly) on their own. We can barely remember the leaner years when we were newly wedded, starting a family, purchasing a home, paying the mortgage, growing a practice, building its walls, testing the waters of friendship, and investing in the larger community. We cannot even hold on to the present, for the ground is trembling beneath us and our balance is getting worse.

\section{HOUSE OF CARDS}

The one mirror in my home is attached to the front of the medicine cabinet. I visit it each day to brush my teeth, shave, and splash a few handfuls of cold water on that lovable face. The morning ritual re-introduces me to the wide grin and twinkling eyes of the 31-yearold doctor who opened his medical practice in Belfast, Maine more than 3 decades ago. The town has changed. My patients are older and dying. The kids have left home. But the wife and I plod along, fixed in our relationship.

I was recently invited to speak in a distant city, which required an overnight stay in a hotel room with a full-length mirror in the bathroom. Travel had been long and cramped, so I was desperate for a cleansing shower. Afterwards, with only a towel draped around my waist, I glanced in the mirror as I left the bathroom... and was astounded to discover a grandfatherly figure who had slipped into the bathroom undetected. He was slightly bent, shorter than me by an inch or 2 , with an unflattering jiggle to his chest and buttocks. Yet he seemed amicable, curious, and not at all startled to see me. He turned when I turned; scratched his ear when I scratched mine. Above his right clavicle was the same mole that I possessed. Could it really be me trapped inside that old man's body?

Our sagging bodies remind us to relax our grip on life, just as our skin has relaxed its grip on us. Let's let a few things loosen and slip away. Appreciate that life is only a temporary stay of execution. For God's sake, engage the man in the mirror! Chat about the people 
we've known, the ideas that lit our mind and heart. While the exterior may look weathered and worn, the interior values - tested and articulated over 33 years in general practice-glisten and shine. Look around! See how much there is to do outside our chosen profession. We have chanced upon a moment steeped in mystery. Blessed it with the spiritual exercise of plowing under and dredging up a lifetime of memories and artifacts.

I have come to know freedom - the freedom of acceptance. Of knowing that my community no longer needs me in the way that it once did-or I once did. Others will capably care for my patients, love them, remember their place among the generations. Let's welcome this gift, celebrate and cherish it. It is the gift of the Sabbath, as Oliver Sacks described it at the end of his life:

Eighty! I can hardly believe it. I often feel that life is about to begin, only to realize that it is almost over... And now weak, short of breath, my once firm muscles melted away by cancer, I find my thoughts, increasingly, not on the supernatural or spiritual but on what is meant by living a good life-achieving a sense of peace within oneself. I find my thoughts drifting to the Sabbath, the day of rest, the 7th day of the week, and perhaps the 7th day of one's life as well, when one can feel that one's work is done, and one may, in good conscience, rest. $^{2}$

I may not be prepared for the Sabbath, but I am tired of the status quo. Tired at the end of each tiring day. To "re-tire" describes both my emotional and transitional state. But I am also eager for something new. Ready to break out of the humdrum. Dismantle (from Middle French, dismantelier) the castle of my career. The word's etymology deepens its meaning: to tear down the walls of the fortress; to remove one's cloak or mantle. To live happily uncloaked. Yet we all know coworkers who have disappeared without a cloak, becoming ghostlike in their retirement. How important, then, it is to know for whom we wish to remain visible.
Not long ago I sat down inside a giant, walk-in camera obscura at our local history museum. As my eyes adjusted to the darkness, a new world emerged in front of me. Cars and people, buildings and street signs floated upside down and backwards. Perhaps this is how we can look at our new lives now, as a world refreshed, reimagined, through the lens of retirement.

We are all pulling on the oars in a crowded boatme, the former employees of the Verso paper mill, the visiting doctors, and my former patients in the Life After Work group. We are dealing with the same sweet sorrow of leaving jobs of a lifetime. Losing our social footing. Waiting to be forgotten, like my poem at the office Christmas party.

Once when I was young, I felt called to the practice of medicine. Therein lies the hope that I will be called again. Sure, it is harder now to wait and listen, or to appreciate the "lesser" opportunities that everywhere abound. But I have no doubt that I can loosen the cloak of my career, or "reshuffle the house of cards," as a friend of mine once put it. To play my hand one card at a time, mindfully and deliberately with those I love. Or play it with joy and abandon, letting the tricks fall where they may. Yet play it we all must. Friends, the hour is later than we think. It is time to play whatever hand we hold.

To read or post commentaries in response to this article, see it online at http://www.AnnFamMed.org/content/16/2/171.

Key words: retirement; primary care; healthy aging

Submitted August 10, 2017; submitted, revised, September 28, 2017; accepted October 23, 2017.

\section{References}

1. Shakespeare W. Romeo and Juliet. Act 2, scene 2.

2. Sacks O. Gratitude. New York, NY, Toronto: Alfred A. Knopf; 2015: 6,45 . 